\title{
ANALISIS YURIDIS PENYIDIKAN TINDAK PIDANA PORNOGRAFI BERDASARKAN UNDANG-UNDANG NOMOR 44 TAHUN 2008 DI ERA DIGITALISASI
}

\author{
Suratman, Andri Winjaya Laksana \\ Dosen Fakultas Hukum UNISSULA \\ andriwinjaya@gmail.com
}

\begin{abstract}
Pornography is a crime that is privacy so that enforcement against the eradication of pornography there are many difficulties. One of the factors inhibiting the eradication of pornography among others due to lack of cooperation from the public and the various parties in reporting this crime. Criminal law enforcement have a tendency to be influenced by the structure of society, that is a constraint that allows the criminal law enforcement can be run and can provide barriers that lead to the enforcement of criminal law can't be started or can't be maximize. As happens to the pros cons on current legislation Law No. 44 Year 2008 concerning the Crime pornography. This research method using normative juridical approach. Normative juridical research also called legal research library research is done by checking library materials or secondary data. The results of the study refers to Article 34 in conjunction with Article 8 of Law No. 44 Year 2008 on Pornography, (1) that the elements of the crime of pornography consists of Subjective elements that error, which means intentionally or consent was committed and objective elements that act (be) which means that objects or models that contain pornographic content. (2) In the process of criminal investigations conducted pornography remains based on Criminal Procedure unless otherwise provided in the Act No. 44 of 2008
\end{abstract}

Keywords : Juridical Analysis, Investigation, The Crime of Pornography

\begin{abstract}
Abstrak
Pornografi merupakan kejahatan yang bersifat privasi sehingga penegakan hukum terhadap pemberantasan pornografi ada banyak kesulitan. Salah satu faktor penghambat pemberantasan pornografi antara lain karena kurangnya kerjasama dari masyarakat dan berbagai pihak dalam melaporkan kejahatan ini. Penegakan hukum pidana memiliki kecenderungan untuk dipengaruhi oleh struktur masyarakat, yang merupakan kendala yang memungkinkan penegakan hukum pidana dapat dijalankan dan dapat memberikan hambatan yang mengarah pada penegakan hukum pidana tidak dapat dijalankan atau tidak dapat memaksimalkan. Seperti yang terjadi pada pro kontra undang-undang Nomor 44 Tahun 2008 tentang Kejahatan pornografi. Metode penelitian ini menggunakan pendekatan yuridis normatif. Hasil penelitian dengan merujuk Pasal 34 jo Pasal 8 Undang-Undang Nomor 44 Tahun 2008 Tentang Pornografi, (1) bahwa unsur-unsur tindak pidana pornografi terdiri dari unsur Subyektif yaitu Kesalahan yang artinya dengan sengaja atau atas persetujuannya perbuatan tersebut dilakukan serta Unsur objektif yaitu Perbuatan (menjadi) yang artinya objek atau model yang mengandung muatan pornografi. (2) Dalam proses penyidikan tindak pidana pornografi dilaksanakan tetap berdasarkan atas Hukum Acara Pidana kecuali ditentukan lain dalam Undang-Undang Nomor 44 Tahun 2008
\end{abstract}

Kata kunci : Analisis Yuridis, Penyidikan, Tindak Pidana Pornografi 


\section{A. PENDAHULUAN}

Indonesia adalah Negara hukum yang berdasarkan Pancasila dan Undang-Undang Dasar Negara Republik Indonesia Tahun 1945 dengan menjunjung tinggi nilai moral, etika, akhlak dan kepribadian luhur bangsa, beriman dan bertakwa kepada Tuhan Yang Maha Esa, serta menghormati kebinekaan dalam kehidupan bermasyarakat, berbangsa dan bernegara serta melindungi harkat dan martabat setiap warga negara. Sesuai dengan perkembangan ilmu pengetahuan dan teknologi khususnya teknologi informasi dan komunikasi telah memberikan andil terhadap meningkatkan perbuatan, penyebarluasan dan penggunaan pornografi yang memberikan pengaruh buruk terhadap moral dan kepribadian luhur bangsa Indonesia sehingga mengancam kehidupan dan tatanan sosial masyarakat Indonesia. Pembangunan hukum nasional meliputi etika pembangunan hukum nasional, Kebijakan Pembangunan Hukum Nasional dan Kebijakan pembangunan hukum nasional.

Penegakan hukum bukanlah merupakan suatu kegiatan yang berdiri sendiri, melainkan mempunyaihubungan timbal balikyang erat dengan masyarakatnya. Oleh karena itu, penegakan hukum dalam sutau masyarakat mempunyai kecenderungan-kecenderungan sendiri yang disebabkan oleh struktur masyarakatnya. Struktur masyarakat tersebut merupakan kendala baik berupa penyediaan sarana sosial yang memungkinkan penegakan hukum dijalankam maupun memberikan hambatan-hambatan yang menyebabkan penegakan hukum tidak dapat dijalankan atau kurang dapat dijalankan dengan seksama. ${ }^{1}$

Menurut Soerjono Sukanto, bahwa masalah pokok dari penegakan hukum terletak pada faktor-faktor yang mempengaruhinya, yakni:

1. Faktor hukum (Undang-Undang);

2. Faktor penegak hukum, yaitu pihak-pihak yang membentuk maupun menerapkan hukum;

3. Faktor sarana atau fasilitas yang mendukung penegakan hukum;

1 Satjipto Rahardjo, 2009, Penegakan Hukum, Genta Publishing, Yogyakarta, hlm 31.
4. Faktor masyarakat yakni lingkungan di mana hukum tersebut berlaku dan diterapkan;

5. Faktor kebudayaan, yakni sebagai hasil karya, cipta dan rasa yang didasarkan pada karsa manusia di dalam pergaulan hidup. $^{2}$

Pembangunan hukum nasional dilaksanakan guna mengantisipasi pesatnya perkembangan dalam berbagai aspek kehidupan masyarakat yang diakibatkan oleh globalisasi di bidang ekonomi dan perdagangan serta perkembangan ilmu pengetahuan dan teknologi menjadikan hukum yang seharusnya sebagai kaidah yang mendahului dinamika masyarakat tidak dapat memainkan perannya sebagai rekayasa sosial yang memberi dasar dan sekaligus arah perkembangan agar tetap sesuai dengan wawasan dan nilai-nilai luhur kepribadian bangsa Indonesia, sehingga upaya kreatif perlu dilakukan baik dalam pelaksanaan pembentukan pembaharuan hukum maupun dalam penegakan hukum dan peningkatan profesionalisme aparatur penegak hukum.

Pesatnya perkembangan teknologi informasi serta mudahnya akses terhadap internet, telah membuka mata kita untuk melakukan penggalian informasi tanpa batas. Dalam kemajuan teknologi tersebut mempermudah akses menuju era digitalisasi. Namun pemanfaatan kemudahan informasi juga dimanfaatkan oleh pihak yang tidak bertanggung jawab dengan meyebarluaskan pornografi melalui internet.

Pornografi menjadi suatu persoalan yang dihadapi oleh bangsa Indonesia pada era globalisasi saat ini, karena perkembangan pornografi bukan hanya terjadi terhadap kehidupan sosial di masyarakat, bahkan penyebarannya secara luas di dunia maya pun terus menjadi suatu hal yang sangat wajar bagi sebagian masyarakat. Ditengah-tengah persoalan mengenai pemberantasan tindak pidana pornografi muncul polemik dalam masyarakat ketika pembentuk undang-undang menetapkan Undang-undang Nomor 44 Tahun 2008 Tentang Pornografi.

Berbagai argumentasi para penolak UndangUndang Nomor 44 Tahun 2008 ini sangatlah

2 Soerjono Soekanto, 1983, Faktor-faktor yang Mempengaruhi Penegakan Hukum, Raja Grafindo Persada, Jakarta, hlm 5. 
variatif. Dari mulai mengangkat isu budaya, eksploitatif terhadap perempuan, bahkan menyangkutpautkan hal ini dengan masalah HAM. Undang-Undang Nomor 44 Tahun 2008 Tentang Pornografi ini masih ada hubungannya dengan ketiga-tiganya. Namun, ada ruang gerak yang membatasi Undang-Undang Nomor 44 Tahun 2008 Tentang Pornografi ini. Ada batasanbatasan yang memang seharusnya digunakan agar tidak menimbulkan kericuhan dalam memahami dan melaksanakan Undang-Undang Nomor 44 Tahun 2008 Tentang Pornografi ini. Penolakan sejumlah elemen masyarakat terhadap Undang-Undang Nomor 44 Tahun 2008 Tentang Pornografi itu tidak lebih dari ikut-ikutan dari apa yang dilihatnya di lapangan. Pihak yang menolak secara total dengan meminta DPR membatalkan pengesahan Undang-Undang Nomor 44 Tahun 2008 Tentang Pornografi itu. Kelompok kedua adalah kalangan yang meminta revisiatas sejumlah pasal. Kelompok ketiga adalah kalangan yang mendukung secara total pemberlakuan Undang-Undang Nomor 44 Tahun 2008 Tentang Pornografi. Pemerintah bersama DPR akhirnya menetapkan UndangUndang Nomor 44 Tahun 2008 Tentang Tindak Pidana Pornografi tersebut dengan beberapa pengecualian kejahatan pornografi yang dilakukan melalui kegiatan kesenian, kebudayaan dan tradisi.

Komitmen mengenai pelarangan pornografi dilakukan dalam segala bentuk terutama secara preventif. Penjelasan Pasal 4 ayat (1) UndangUndang Nomor 44 Tahun 2008 Tentang Pornografi justru melemahkan keseriusan pengaturan $\mathrm{Pasal}$ 4 Undang-Undang Pornografi yang melarang semua bentuk muatan pornografi dengan segala bentuk dan tujuannya. Penjelasan Pasal 4 Undang-Undang Nomor 44 Tentang Pornografi justru menjadi kesalahan fatal karena sangat berpotensi untuk menciptakan pelanggaran pada Pasal 4 Undang-Undang Pornografi. Pengaturan tersebut membawa implikasi bahwa pembuatan pornografi untuk keperluan diri sendiri tidak dilarang, tetapi menjadi dilarang ketika pornografi tersebut disebarluaskan ke pada pihak ketiga.

Dalam konteks hukum positif, konsep tentang pornografi dapat juga ditemukan dalam beberapa ketentuan perundang-undangan. Dalam KUHP, misalnya walaupun tidak menyebutkan secara eksplisit mengenai definisi pornografi tersebut. Batasan pengertian pornografi dalam KUHP hanyalah disebut sebagai kejahatan terhadap kesusilaan atau kejahatan terhadap kesopanan. Namun apabila dilihat dari bentuk-bentuk kejahatan yang diatur dalam KUHP tersebut, maka kesemuanya termasuk dalam kategori pornografi. Walaupun demikian berdasarkan pada pengertian tentang apa yang dimaksud dengan kesopanan atau kesusilaan menunjukkan dalam KUHP tidak terdapat adanya legalisasi yang mengatur masalah pornografi.

Dari fakta yang ada penulis menentukan perumusan masalah yang akan di bahas dalam jurnal ini yaitu

1. Apa Unsur-Unsur tindak pidana Pornografi menurut Undang-Undang Nomor 44 Tahun 2008 Tentang?

2. Bagaimana penyidikan Terhadap Tindak Pidana Pornografi?

\section{B. METODE PENELITIAN}

Metode Penelitian yang digunakan adalah metode pendekatan yuridis normatif. Penelitian normatif atau disebut juga penelitian hukum kepustakaan adalah penelitian hukum yang dilakukan dengan cara meneliti bahan pustaka atau data sekunder, kemudian untuk diterapkan pada masalah penelitian yakni unsur-unsur tindak pidana pornografi dan penyidikan terhadap tindak pidana pornografi sehingga penyajiannya berpangkal pada asas-asas dan teori-teori dan doktrin serta perundangUndangan yang berlaku. ${ }^{3}$

Spesifikasi penelitian ini adalah bersifat deskriptif sesuai dengan masalah dan tujuan dalam penelitian. Penelitian dengan menggambarkan sejumlah variabel yang berkenaan dengan masalah yang diteliti. Dengan kata lain penelitian ini hanya terbatas pada penggambaran satu atau lebih mengenai analisis yuridis penyidikan tindak pidana pornografi berdasarkan undangundang nomor 44 tahun 2008 di era digitalisasi.

3 Salim HS dan Erlies Septiana Nurbani, 2013, Penerapan Teori Hukum pada Penelitian Tesis dan Disertasi, Raja Grafindo Persada, Jakarta, hlm.12. 
C. HASIL PENELITIAN DAN PEMBAHASAN

1. Unsur-Unsur Tindak Pidana Pornografi menurut Undang-Undang Nomor 44 Tahun 2008 Tentang Pornografi

Globalisasi dan perkembangan ilmu pengetahuan dan teknologi khususnya teknologi informasi dan komunikasi telah memberikan andil terhadap meningkatkan perbuatan, penyebarluasan dan penggunaan pornografi yang memberikan pengaruh buruk terhadap moral dan kepribadian luhur bangsa Indonesia sehingga mengancam kehidupan dan tatanan sosial masyarakat Indonesia. ${ }^{4}$

Dampak negatif dari kemajuan teknologi secara mudah mempengaruhi kehidupan masyarakat melalui kemajuan teknologi dan rasa membutuhkan masyarakat akan teknologi. Salahsatu dampak negatif dari kemajuan teknologi adalah terus bertambahnya jenis tindak pidana baru termasuk tindak pidana pornografi. Pornografi adalah perbuatan yang berdampak negatif terhadap perilaku generasi muda. Anakanak dan perempuan banyak yang telah menjadi korban.

Berlakunya undang-undang Nomor 44 Tahun 2008 Tentang Pornografi menimbulkan berbagai kontroversi. Banyak orang yang berpendapat bahwa undang-undang pornografi dapat mengekang kebebasan berekspresi, jadi Undang-undang tersebut bertentangan dengan semangat demokrasi. Namun Undang-Undang pornografi ini merupakan kebutuhan yang sangat mendesak untuk Indonesia. Karena diera digitalisasi seperti sekarang ini sangat diperlukan aturan sebagai payung hukum pemberantasan tindak pidana pornografi.

Unsur yang ditunjuk oleh Pasal 34 adalah perbuatan yang sama dengan perbuatan pada Pasal 8 Undang-Undang Nomor 44 Tahun 2008 Tentang Pornografi. Apabila rumusan Pasal 34 Jo Pasal 8 Undang-Undang Nomor 44 Tahun 2008

4 Penjelasan Undang-Undang Nomor 44 Tahun 2008 Tentang Pornografi.
Tentang Pornografi dirinci maka terdiri dari unsur-unsur sebagai berikut:

a. Unsur Subyektif

Kesalahan : dengan sengaja atau atas persetujuannya

b. Unsur objektif

Perbuatan : menjadi

Objeknya: objek atau model yang mengandung muatan pornografi.

Dari unsur objektif dan subyektif tersebut diatas dapat dijelaskan secara lebih rinci sebagai berikut :

1. Kesalahan dengan Sengaja

Semua tindak pidana pornografi adalah tindak pidana dolus (sengaja). Namun hanya tindak pidana pada Pasal 34 Undang-Undang Nomor 44 Tahun 2008 Tentang Pornografi ini yang mencantumkan secara tegas dengan sengaja. Sementara itu tindak pidana pornografi dalam UndangUndang Nomor 44 Tahun 2008 Tentang Pornografi ini tidak mencantumkan kata-kata dengan sengaja. Meskipun tidak mencantumkan unsur sengaja dalam rumusannya, tindak pidana pornografi lainnya dalam UndangUndang Nomor 44 Tahun 2008 Tentang Pornografi ini merupakan tindak pidana sengaja. Unsur sengaja terdapat secara terselubung atau diam dalam unsur perbuatan. Sebagaimana sistem Wvs Belanda, bahwa semua tindak pidana yang tidak mencatumkan unsur sengaja maupun kulpa, maka tindak pidana tersebut merupakan tindak pidana sengaja.

Sebagaimana yang dikatakan oleh Moeljatno bahwa bilamana unsur-unsur sengaja ataiu kata lain sesamanya tidak dicantumkan dalam rumusan tindak pidana. Dalam tindak pidana tersebut tetap diperlukan adanya unsur sengaja bagi kesalahan terdakwa karena telah menjadi sistem wetboek van strafrecht bahwa kejahatan selalu diperlukan adanya kesengajaan, 
kecuali ditentukan dengan nyata lain (kealpaan). ${ }^{5}$

Sejalan dengan hal itu, Jam Rememlink menyatakan bahwa unsur sengaja tersebut dapat tersembunyi di dalam cara bagaimana suatu tindakan dilakukan, yaitu bilamana dalam kata kerja yang dipergunakan rumusan delik sudah terkait unsur dolus, misalnya dengan kekerasan atau ancaman melawan atau memaksa dengan kekerasan atau ancaman kekerasan. ${ }^{6}$ Dalam rumusan tindak pidana selalu mengandung arti bahwa si pembuat menghendaki untuk mewujudkan perbuatan yang dilarang dan mengetahui semua unsur yang letaknya dimuka unsur sengaja. Inilah arti kesengajaan dalam hubungannya dengan kompleksitas unsur-unsur lain dalam rumusan tindak pidana. Mencari arti kesengajaan harus dihubungkan dengan unsur-unsur lain dalam kompleksitas unsur tindak pidana yang dirumuskan.

Pengertian sengaja sebagaimana yang dimaksudkan sangat penting dan mutlak diperlukan daam pembuktian. Oleh karena itu, membuktikan tindak pidana telah terwujud sempurna, sama artinya membuktikan setiap unsur yang terdapat dalam peristiwa yang didakwakan. Membuktikan setiap unsur diperlukan penarikan arti dari unsur tersebut

Ada 3 (tiga) keadaan penting yang perlu diperhatikan dalam hal membuktikan unsur sengaja dalam rumusan tindak pidana, yaitu:

1. Hubungan sengaja dengan unsur lain dalam rumusan tindak pidana

Suatu unsur tindak pidana tidak berdiri sendiri, tetapi selalu berhubungan dengan unsur

5 Moeljatno, 1983, Asas-asas Hukum Pidana, Bina Aksara, Jakarta, hlm 179.

6 Jan Remelink, 2003, Hukum Pidana Komentar atas Pasal-pasal Terpenting dalam KUHP Belanda dan Pidananya dalam KUHP Indonesia, Grafmedia Pustaka Utama, Jakarta, hlm 161. lain yang dicantumkan dalam rumusan. Mengenai hubungan sengaja dengan unsur lainnya dalam rumusan tindak pidana dalam Memorie van Toelichting (MvT) WvS Nederland. MvT WvS Belanda memberi petunjuk bahwa opzettelijk plegen ban een misdriff is het teweegbrengen ban verboden handeling willens en wetens. Artinya sengaja melakukan suatu kejahatan adalah melakukan perbuatan yang dilarang dengan dikehendaki dan diketahui. Singkatnya, sengaja adalah sebagai kehendak (willens) dan pengetahuan (wtens). Misalnya sikap batin orang yang menghendaki dan mengetahui unsur suatu perbuatan dan lain-lain yang menjadi unsur tindak pidana. Si pembuat menghendaki untuk mewujudkan tindak pidana, menghendaki perbuatan serta unsur-unsur lain dan mengetahui semua unsur yang ada di dalam tindak pidana. Mengetahui mengandung arti memahami, menyadari, menginsyafi, mengerti. Ukuran pemahaman atau pengertian tidak perlu dari sudut konsep-konsep yuridis yang rumit, seperti yang dimiliki oleh ahli hukum. Akan tetapi, cukup pengetahuan orang pada umumnya, pengetahuan orang awam saja. ${ }^{7}$

Moeljatno menyebut petunjuk dalam MvT tersebut dengan kunci Modderman. Mengikuti petunjuk MvT, maka ada dua hal yang perli diturut dalam membuktikan unsur sengaja dalam rumusan ini yakni

2. Tentang arti sengaja sebagai kehendak dan pengetahuan

7 PAF Lamintang, 1990, Dasar-dasar Hukum Pidana Indonesia, Sinar Baru, Bandung, hIm 268. 
3. Kearah mana kehendak dan pengetahuan tersebut ditujukan pada semua unsur yang diletakkan di muka kata sengaja dalam kalimat rumusan tindak pidana. ${ }^{8}$. Dengan kata lain semua unsur yang diletakkan di muka sengaja menentukan ke arah mana sengaja harus ditujukan. Unsur yang hampir pasti diletakkan di depan sengaja adalah unsur perbuatan dan objek perbuatan, yang seklaigus merupakan objek tindak pidana. Selanjutnya barulah unsur-unsur lainnya, Misalnya unsur keadaan menyertai objek atau menyertai perbuatan dan keadaankeadaan lainnya. Oleh karena itu, frasa objek atau model yang mengandung muatan pornografi dalam rumusan Pasal 34 UndangUndang Pornografi merupakan unsur objek tindak pidana. Unsur obyek itu pasti selalu diarahkan ataui ditujukan oleh kesengajaan

Sesuai dengan petunjuk dari MvT WvS Belanda tersebut, kesengajaan dalam Pasal 34 mengandug arti bahwa si pembuat menghendaki menjadi objek atau model yang bermuatan pornografi. Frasa atas persetujuannya dalam rumusan Pasal 34 sama artinya dengan menghendaki. Di sini disadari bahwa objek atau model yang dikehendakinya adalah bermuatan pornografi. Atas pengetahuan semacam ini si pembuat menghendaki menjadi objek atau model yang bermuatan porografi

Unsur kesalahan dalam rumusan Pasal 34 Undang-Undang Pornografi ditulis "dengan sengaja atau atas persetujuannya" dihubungkan dengan perbuatan, objek perbuatan dan objek tindak pidana sebagaimana dirinci tersebut dapat dijelaskan sebagai berikut:
1. Ditinjau dari sudut adanya kehendak. Dengan sengaja sama artinya dengan atas persetujuannya. Menghendaki dalam unsur sengaja menjadi objek atau model sama dengan menghendaki dalam unsur atas persetujuan dirinya untuk menjadi objek atau model yang bermuatan pornografi.

2. Ditinjau dari sudut asalnya inisiatif timbulnya kehendak, "dengan sengaja" berbeda dari "atas persetujuannya". Inisiatif timbulnya kehendak dalam kesalahan dengan sengaja sejak semula berasal dari si pembuat sendiri. Si pembuat yang menjadi obyek atau model yang bermuatan pornografi sementara dalam kesalahan atas persetujuannya inisiatif timbul dari kehendak untuk menjadi objek atau model pornografi berasal dari orang lain. Dirinya untuk dijadikan objek atau model sekedar menyetujui.

\section{Proses Penyidikan Tindak Pidana Pornografi.}

Pornografi memiliki konsep sebagai tindakan yang jelas latar belakangnya baik secara historis dan terminologis, konteks sosial sejarah, maupun sebagai konsep hukum sebuah konstruksi tindak pidana. Pornografi dalam KUHP di Indonesia diatur dalam Pasal 282 mengenai kejahatan pornografi, Pasal 283 mengenai kejahatan pornografi terhadap orang yang belum dewasa, Pasal 283 bis tentang kejahatan pornografi dalam menjalankan mata pencaharian, pasal 532 dan pasal 533 mengenai pelanggaran pornografi.

Pornografi bisa dikatakan perbuatan yang merusak kesusilaan (schennis der eerbaarheid). Kesusilaan yang dirusak sebenarnya adalah apa yang dirasakan sebagai kesusilaan oleh segenap orang dalam suatu masyarakat sehingga dapat

8 Moeljatno, Op. Cit., hlm 14. 
dikatakan bahwa yang tersinggung adalah rasa susila dari semua orang dalam masyarakat tersebut. Rumusan tersebut merupakan rumusan yang sifatnya abstrak sebab perbuatan-perbuatan yang dirumuskan oleh pembentuk undangundang, isi dan wujud konkritnya tidak dapat ditentukan (wujud konkritnya sangat banyak bahkan tidak terbatas atau wujud perbuatannya baru dapat diketahui pada saat perbuatan itu telah terjadi secara sempurna). ${ }^{9}$

Tindak pidana pornografi pada dasarnya telah menjadi kebiasaan yang terus berkembang bagikan bola es yang terus bergulir semakin besar, salah satu contoh kasus pornografi yang terjadi di dalam masyarakat yang berhasil diungkap ketika Direktorat Tindak Pidana Ekonomi Khusus Badan Reserse Kriminal Kepolisian Republik Indonesia berhasil mengungkap perdagangan 14.000 video porno "online" yang di dalamnya terdapat konten yang melibatkan anakanak atau "child pornography online". Dalam perdagangan video porno tersebut, tidak semua orang dapat mengakses situs yang digunakan untuk menjual video porno, karena situs perdagangan video porno kunci dengan menggunakan password. Setelah penemuan situs yang diketahui melakukan perdagangan video porno tersebut, kepolisian melakukan langkah preventif yaitu dengan melakukan pemblokiran situs. ${ }^{10}$

Modus operandi pelaku dalam melakukan perdagangan video porno tersebut, pelaku mengunduh video porno lewat internet dan kemudian diunggah kembali ke situs yang dikelola pelaku untuk melakukan perdagangan tersebut. Untuk mendapatkan video porno tersebut, setiap orang harus mendaftar sesuai paket yang diinginkan

9 J.M. van Bemmelen, 1986, Hukum Pidana 3 bagian Khusus Delik-Delik Khusus, Bina Cipta, hlm.177-178.

10 http://bandung.bisnis.com/read/20140224/34239/ 497134/berkat-penyamaran-kasus-pornografi-anakdi-bandung-terungkap, diakses pada tanggal 12 Desember 2013. dari Rp.30.000 hingga Rp.800.000. Pembayaran dilakukan melalui transfer, bukti transfer kemudian dikirim kepada pelaku, kemudian pelanggan diberikan kode belakang nomor ponsel pelanggan tersebut. Berdasarkan ketentuan Pasal 29 Undang-Undang Nomor 44 Tahun 2008 tentang Pornografi, pelaku diancam dengan sanksi hukuman paling lama 12 tahun atau denda paling banyak Rp 6 miliar dan Pasal 27 ayat (1) Pasal 52 Undang-Undang Informasi dan Transaksi Elektronik dengan sanksi hukuman maksimal delapan tahun dan atau denda paling banyak Rp 1 miliar. Ketentuan kedua pasal tersebut, ditambah satu per tiga dari maksimum ancaman pidana karena pelaku melibatkan anak-anak dalam tindak kejahatannya. ${ }^{11}$

Di dalam upaya penegakan hukum terhadap tindak pidana pornografi, Kepolisian berwenang melakukan penyidikan seperti yang diatur di dalam Pasal 23 Undang-Undang Nomor 44 Tahun 2008 Tentang Pornografi, bahwa mengenai penyidikan terhadap tindak pidana pornografi dilaksanakan berdasarkan Kitab Undang-undang Hukum Acara Pidana kecuali ditentukan lain dalam Undang-Undang Nomor 44 Tahun 2008. Pengecualian-pengecualian di dalam Undang-Undang Nomor 44 Tahun 2008 Tentang Pornografi di dalam proses penyidikan oleh Polri antara lain di dalam Pasal 24 yakni bahwa di samping alat bukti sebagaimana diatur di dalam Undang-Undang tentang Hukum acara Pidana, termasuk juga alat bukti dalam tindak pidana meliputi tetapi tidak terbatas pada barang yang memuat tulisan atau gambar dalam bentuk cetakan atau bukan cetakan, baik elektronik, optik maupun bentuk penyimpanan data lainnya dan data yang tersimpan dalam jaringan internet dan saluran komunikasi lainnya

Kemudian Pasal 25 Undang-Undang Nomor 44 Tahun 2008 Tentang Pornografi mengatur bahwa untuk kepentingan

11 Ibid. 
penyidikan, penyidik berwenang membuka akses, memeriksa dan membuat salinan data elektrobik yang tersimpan di dalam file komputer, jaringan internet, media optik, serta bentuk penyimpanan data elektronik lainnya dan untuk kepentingan penyidikan, pemilik data, penyimpan data atau penyedia jasa layanan elektronik berkewajiban menyerahkan dan atau membuka data elektronik yang diminta penyidik. Dan pemilik data, penyimpan data atau penyedia jasa layanan elektronik setelah menyerahkan dan atau membuka data elektronik tersebut berhak menerima tanda terima penyerahan atau berita acara pembukaan data elektronik dari penyidik.

Pasal 26 Undang-Undang Nomor 44 Tahun 2008 Tentang Pornografi menyatakan, bahwa penyidik membuat berita acara tentang tindakan kemudian mengirimkan turunan berita acara tersebut kepada pemilik data, penyimpan data atau penyedia jasa layanan komunikasi di tempat data tersebut didapatkan.

Kemudian Pasal 27 UndangUndang Nomor 44 Tahun 2008 Tentang Pornografi mengatur bahwa data yang ada hubungannya dengan perkara yang sedang diperiksa dilampirkan di dalam berkas perkara, dan dapat dimusnahkan atau dihapus. Penyidik, penuntut umum dan para pejabat pada semua tingkat pemeriksaan dalam proses peradilan wajib merahasiakan dengan sungguhsungguh atas kekuatan sumpah jabatan baik isi maupun informasi data elektronik yang dimusnahkan atau dihapus tersebut.

Penyidik, penuntut umum dan para pejabat pada semua tingkat pemeriksaan dalam proses peradilan wajib merahasiakan dengan sungguhsungguh atas kekuatan sumpah jabatan baik isi maupun informasi data elektronik yang dimusnahkan atau dihapus tersebut.

Penegakan hukum bukanlah merupakan suatu kegiatan yang berdiri sendiri, melainkan mempunyai hubungan timbal balik yang erat dengan masyarakatnya. Oleh karena itu, penegakan hukum dalam sutau masyarakat mempunyai kecenderungankecenderungan sendiri yang disebabkan oleh struktur masyarakatnya. Struktur masyarakat tersebut merupakan kendala baik berupa penyediaan sarana sosial yang memungkinkan pelaksanaan penegakan hukum dijalankan maupun memberikan hambatan yang dapat menyebabkan penegakan hukum tidak dapat dijalankan atau kurang dapat dijalankan dengan seksama. ${ }^{12}$

Pada hakekatnya berbicara tentang penegakan ide-ide, serta konsep-konsep yang notabene adalah abstrak. Penegakan hukum merupakan suatu usaha untuk mewujudkan ide-ide tersebut menjadi kenyataan. Proses perwujudan ideide tersebut merupakan hakekat dari penegakan hukum. Apabila berbicara mengenai perwujudan ide yang abstrak menjadi kenyataan, maka sebenarnya sudah memasuki bidang manajemen. ${ }^{13}$

\section{PENUTUP}

\section{Kesimpulan}

a. Unsur Pornografi berdasakan UndangUndang Nomor 44 Tahun 2008 Tentang Tindak Pidana Pornografi dimuat dalam Pasal 8 dan 34, Unsur yang ditunjuk oleh Pasal 34 adalah perbuatan yang sama dengan perbuatan pada Pasal 8 UndangUndang Nomor 44 Tahun 2008 Tentang Pornografi. Unsur tindak pidana pornografi pada rumusan Pasal 34 jo Pasal 8 Undang-Undang Nomor 44 Tahun 2008 terdiri dari unsur Subyektif yaitu Kesalahan yang artinya dengan sengaja atau atas persetujuannya perbuatan tersebut dilakukan. Serta Unsur objektif yaitu Perbuatan (menjadi) yang artinya objek atau model yang mengandung muatan pornografi.

12 Satjipto Rahardjo,Op.Cit. hlm 31.

13 Karjadi, 1978, Polisi, Filsafat dan Perkembangan Hukumnya, Politea, Bogor,hlm 36. 
b. Pelaksanaan penyidikan terhadap tindak pidana pornografi diatur di dalam Pasal 23 Undang-Undang Nomor 44 Tahun 2008 Tentang Pornografi bahwa penyidikan terhadap tindak pidana pornografi dilaksanakan sesuai dengan KUHAP kecuali ditentukan lain dalam Undang-Undang Nomor 44 Tahun 2008. Pengecualian dalam Undang-undang Nomor 44 Tahun 2008 terdapat dalam Pasal 24, 25, 26 dan 27.

\section{Saran}

a. Dalam mensikapi tentang tindak pidana pornografi hendaklah kita menyamakan persepsi mengenai bahaya pornografi bukan mencari alasan pembenar berkaitan dengan konsep pornografi yang dipandang premature. Pornografi adalah faktor terbesar dalam perusakan generasi muda Indonesia, dalam pelaksanaan penegakan hukum pidana terhadap tindak pidana pornografi sangat diperlukan peran serta kerjasama dari masyarakat dan penegak penegak hukum demi terciptanya masyarakat adil dan makmur.

\section{DAFTAR PUSTAKA}

\section{- Buku-buku}

Jan Remelink, 2003, Hukum Pidana Komentar atas Pasal-pasal Terpenting dalam KUHP Belanda dan Pidananya dalam KUHP Indonesia, Grafmedia Pustaka Utama, Jakarta. Moeljatno, 1983, Asas-asas Hukum Pidana, Bina Aksara, Jakarta.

PAF Lamintang, 1984, Dasar-dasar Hukum Pidana di Indonesia, Sinar Baru, Bandung. SA. Soehardi, 2004, Polisi Penegak Hukum yang Pelayan, Media Agung Persada, Semarang. Satjipto Rahardjo, 1983, Masalah Penegakan Hukum; Suatu Tinjauan Sosiologis, Badan Pembinaan Hukum Nasional Departemen Kehakiman, Jakarta.

Soerjono Soekanto, 1982, Penelitian Hukum Normatif Suatu Tinjauan Singkat, Rajawali, Jakarta. 1983, Faktor-faktor yang Mempengaruhi Penegakan Hukum, RajaGrafindo Persada, Jakarta.

\section{- Peraturan Perundang-undangan:}

Kitab Undang-Undang Hukum Pidana;

Kitab Undang-Undang Hukum Acara Pidana;

Undang-Undang Nomor 2 Tahun 2002 Tentang Kepolisian Negara Republik Indonesia; Undang-Undang Nomor 44 Tahun 2008 Tentang Pornografi;

\section{- Internet :}

http://bandung.bisnis.com/read/20140224/34239/497134/berkat-penyamaran-kasus-pornografianak-di-bandung-terungkap, 